\title{
A DITOX derived $\alpha$-sulfinyl carbanion as nucleophile in conjugate addition reactions to pyrrolo[2,1-a]isoquinolones
}

\author{
Cristina Camarero, Sonia Arrasate, Nuria Sotomayor, and Esther Lete* \\ Departamento de Química Orgánica II, Facultad de Ciencia y Tecnología, Universidad del País \\ Vasco, Apdo. 644. 48080 Bilbao, Spain \\ E-mail: esther.lete@ehu.es
}

Dedicated to Professor Benito Alcaide on occasion of his $60^{\text {th }}$ birthday

\begin{abstract}
The synthesis of DITOX, both in racemic and enantioenriched forms, was accomplished via sulfur oxidation of 1,3-dithiane or 2-acyl-1,3-dithiane derivatives, using chiral oxaziridines for the asymmetric process. The conjugate addition reaction of the $\alpha$-sulfinyl carbanion derived from DITOX, prepared by deprotonation using the mixture of bases NaHMDS $/ n$-BuLi, to the bicyclic $\gamma$-lactam unit of $\mathrm{C}-10 \mathrm{~b}$ substituted dihydropyrrolo[2,1-a]isoquinolones led diastereoselectively to the corresponding trans isomer.
\end{abstract}

Keywords: DITOX, pyrroloisoquinolines, conjugate addition, asymmetric oxidation, $\alpha$-sulfinyl carbanion

\section{Introduction}

Asymmetric 1,4-addition reactions to $\alpha, \beta$-unsaturated carbonyl compounds are among the most frequently used methods for stereoselective $\mathrm{C}-\mathrm{C}$ bond construction. ${ }^{1}$ The utilization of chiral sulfur-based stabilized carbanions has shown great promise as a powerful method in asymmetric Michael-type reactions. ${ }^{2}$ Thus, Toru et al. have reported that the reaction of chiral $\alpha$-sulfinyl carbanions derived from $p$-tolyl $\beta$-(trimethylsilyl)ethyl sulfoxides with $\alpha, \beta$-unsaturated carbonyl compounds or esters gives the conjugate addition products with complete stereoselectivity. ${ }^{3}$ Álvarez-Ibarra and co-workers reported high levels of stereoselectivity in 1,4-additions of anions derived of a $\alpha$-sulfinylketimine to an $\alpha, \beta$-unsaturated ester, which has culminated in the enantioselective synthesis of methyl $(+)-(2 S, 4 S)-4-$ methylpipecolate. ${ }^{4}$ Similar results were achieved by Metzner, ${ }^{5}$ who has used anions prepared from chiral $\alpha$-sulfinylthioamide in the same type of reaction with $\alpha, \beta$-unsaturated ester and nitriles as substrates. 
1,3-Dithiane 1-oxide (DITOX) derivatives, which both enantiomers can be accessed with excellent enantioselectivities by asymmetric sulfur oxidation of the corresponding 1,3-dithianes, can act as combined chiral auxiliaries and asymmetric building blocks. ${ }^{6}$ It has been shown that chiral and achiral carbanions derived from DITOX and its 2-acyl derivatives undergo a variety of transformations with excellent diastereoselectivities, including nucleophilic substitution of alkyl halides, ${ }^{7}$ nucleophilic addition to aldehydes, ketones, esters or $N$-acylimidazoles, ${ }^{8}$ and electrophilic amination. ${ }^{9}$ In addition, different types of stereoselective reactions using the DITOX unit as the stereocontrolling element, have been described, as well as its application to the enantioselective synthesis of several interesting compounds, such as $\alpha$-hydroxyacids or $\alpha$ arylpropano acids. ${ }^{10}$ However, to the best of our knowledge, there are no precedents in the literature for the 1,4-addition of $\alpha$-sulfinyl carbanions derived from DITOX to $\alpha, \beta$-unsaturated carbonyl compounds.

In this context, our group has been involved in the application of conjugate addition reactions to $\alpha, \beta$-unsaturated lactams in the synthesis of polyfunctionalized nitrogen heterocycles. In this context, we have recently described a stereocontrolled 1,4-addition of $\alpha$-lithiodithioacetals to tetrahydrobenzo $[a]$ benzoquinolizines, which led to the synthesis of emetine-like derivatives. ${ }^{11}$ On the other hand, the introduction of a carbomethoxy group in the $\alpha$-position of $\alpha, \beta$ unsaturated bicyclic $\gamma$-lactams ${ }^{12}$ has allowed us to achieve the conjugate addition of hard nucleophiles to pyrrolo[2,1-a]isoquinolones, ${ }^{13}$ as we had previously illustrated in the synthesis of erythrinanes. ${ }^{14}$ In this paper, we describe the use of $\alpha$-sulfinyl carbanions derived from DITOX in 1,4-addition reactions to the $\alpha, \beta$-unsaturated lactam unit of pyrrolo[2,1-a]isoquinolone $\mathbf{1}$ (Scheme 1).

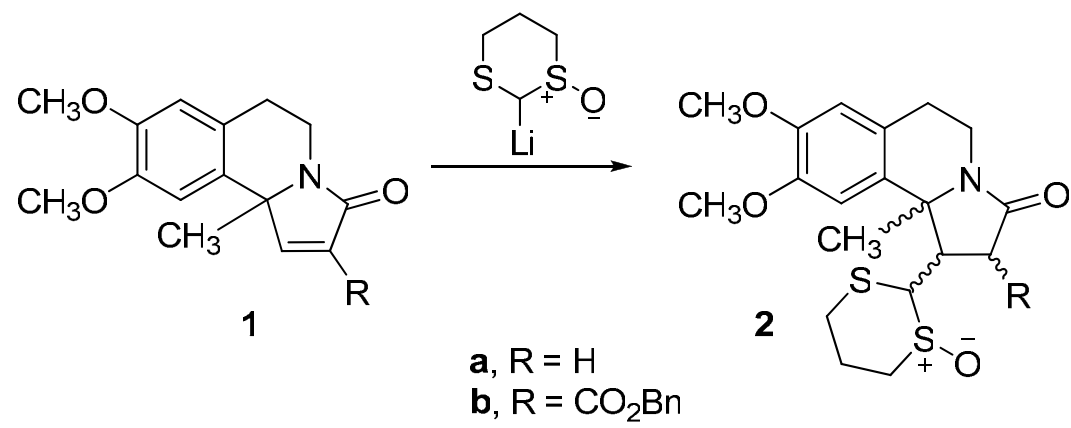

\section{Scheme 1}

\section{Results and Discussion}

Our first task was the synthesis of racemic DITOX (3), which was accomplished by treatment of 1,3-dithiane with $m$-CPBA at room temperature overnight. Although several experimental 
conditions were tried, the low yields of the monoxide could not be improved, due to the formation of the corresponding dioxide and/or sulfone. ${ }^{15}$

To check that $\alpha$-sulfinyl carbanion derived from DITOX was efficiently formed, we carried out the deprotonation of $\mathbf{3}$ using Page procedure, ${ }^{7 c, 8 b}$ with sodium hexamethyldisilazide at $-78^{\circ} \mathrm{C}$ in THF solution, subsequent treatment with $n$-BuLi and addition of the electrophile (ethyl 2,2-dimethylpropanoate), obtaining the corresponding 2-acyl-DITOX 4 as a diastereomeric mixture in a 70:30 ratio (Scheme 2).

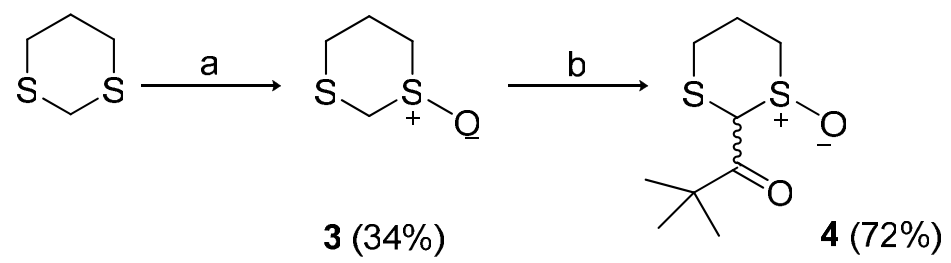

Scheme 2. Reagents and conditions: (a) $m$-CPBA, $\mathrm{K}_{2} \mathrm{CO}_{3}, \mathrm{CH}_{2} \mathrm{Cl}_{2}, 0^{\circ} \mathrm{C}$ to $\mathrm{rt}, 16 \mathrm{~h}$. (b) NaHMDS, THF, $-78^{\circ} \mathrm{C}, 10 \mathrm{~min} ; n$-BuLi, $-78^{\circ} \mathrm{C}, 10 \mathrm{~min} ;\left(\mathrm{CH}_{3}\right)_{3} \mathrm{CCO}_{2} \mathrm{Et},-78^{\circ} \mathrm{C}$ to rt, $2 \mathrm{~h}$.

We next undertook the asymmetric synthesis of $(+)-(S)$-DITOX by asymmetric sulfur oxidation of 1,3-dithiane using Davies' oxaziridines. ${ }^{16}$ As shown in Scheme 3, treatment of commercial (-)-(3-oxocamphorylsulfonyl)imine with $\mathrm{CH}\left(\mathrm{OCH}_{3}\right)_{3}$ and $\mathrm{H}_{2} \mathrm{SO}_{4}$ in $\mathrm{MeOH}$ afforded imine 5 in quantitative yield and excellent enantiomeric excess. Subsequent oxidation with $m$ CPBA gave oxaziridine 6, again in excellent yields and with very high enantiomeric excess. The enantiomeric purity of both compounds was determined by comparison of the $[\alpha]^{23}$ value with the literature values. ${ }^{17}$

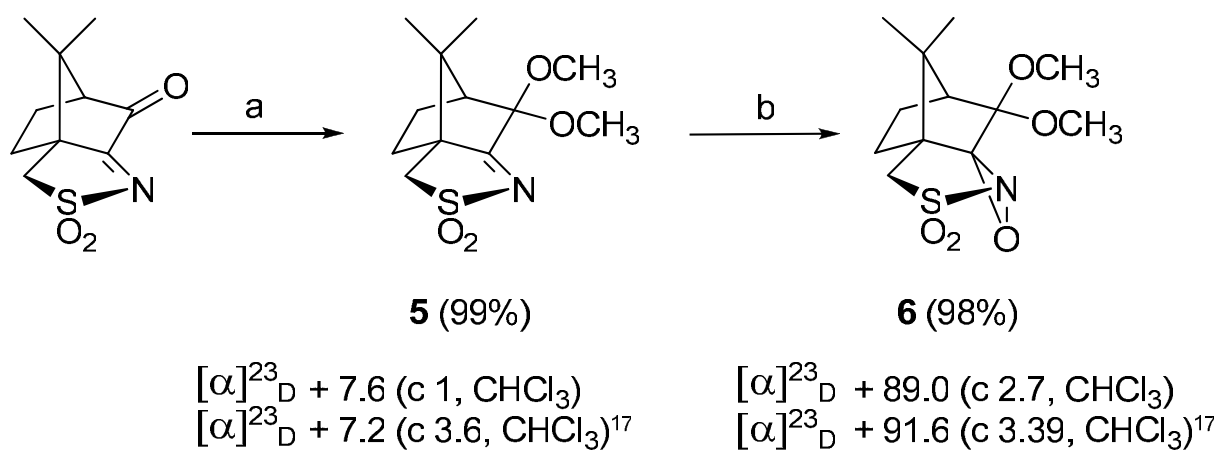

Scheme 3. Reagents and conditions: (a) $\mathrm{CH}\left(\mathrm{OCH}_{3}\right)_{3}, \mathrm{H}_{2} \mathrm{SO}_{4}, \mathrm{MeOH}, 85-90{ }^{\circ} \mathrm{C}, 4 \mathrm{~h}$; $\mathrm{CH}\left(\mathrm{OCH}_{3}\right)_{3}, \mathrm{MeOH}$, rt to $85-90^{\circ} \mathrm{C}, 1$ h. (b) $m$-CPBA, $\mathrm{K}_{2} \mathrm{CO}_{3}, \mathrm{CH}_{2} \mathrm{Cl}_{2}$, rt $16 \mathrm{~h}$.

It is known that asymmetric sulfur oxidation on 1,3-dithianes requires the introduction of an acyl group at C-2 to be successful. ${ }^{6}$ Thus, 1,3-dithiane was deprotonated by sequential addition of NaHMDS and $n$-BuLi at $0^{\circ} \mathrm{C}$ as described above, and the so-obtained 1,3-dithianyllithium 
reacted with $\left(\mathrm{CH}_{3}\right)_{3} \mathrm{CCO}_{2} \mathrm{Et}$ to afford the 2-acyl-1,3-dithiane 7 in a $63 \%$ yield. Asymmetric sulfur oxidation was accomplished upon treatment of a solution of 7 in $\mathrm{CCl}_{4}$ with oxaziridine 6 to afford sulfoxide 4 in quantitative yield as a mixture of diastereomers. Finally, elimination of the pivaloyl group by treatment with aqueous $(5 \%) \mathrm{NaOH}$ under reflux gave (-)-(S)-DITOX 3 in good yield. The enantiomeric excess determined by CSP HPLC was $66 \%$ (lit. ${ }^{17} 87 \%$ ) by comparison with the racemic mixture (Chiralcel OD, 9\% hexane/2-propanol). The value of the specific rotation (see scheme 4) allowed us to assign the absolute configuration of sulfoxide as $S$.

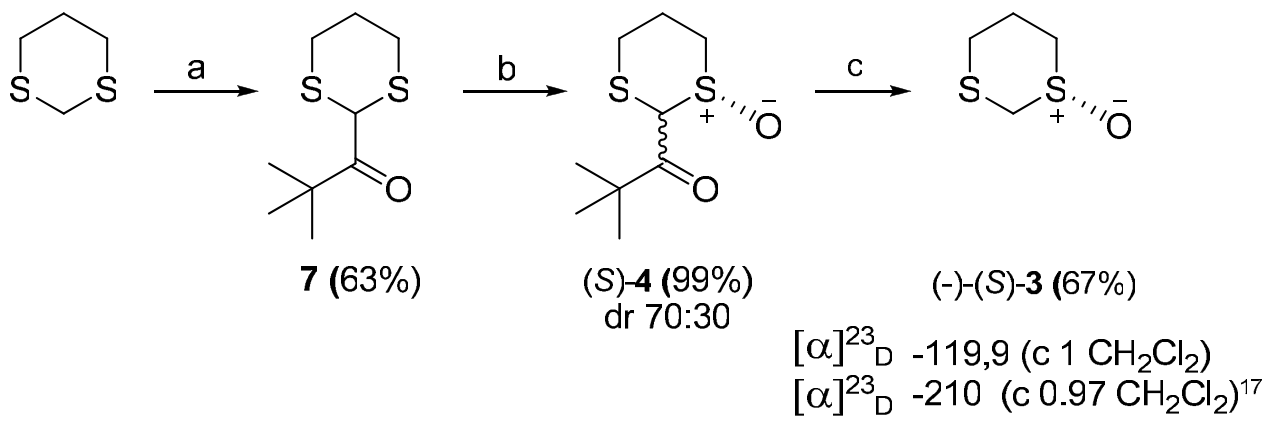

Scheme 4. Reagents and conditions: (a) NaHMDS, THF, $0^{\circ} \mathrm{C}$ to $\mathrm{rt}, 1 \mathrm{~h} ; n-\mathrm{BuLi}, 0^{\circ} \mathrm{C}$ to $\mathrm{rt}$, 30min; $\left(\mathrm{CH}_{3}\right)_{3} \mathrm{CCO}_{2} \mathrm{Et}$, rt, $2.5 \mathrm{~h}$ (b) Oxaziridine 6, $\mathrm{CCl}_{4}, 0{ }^{\circ} \mathrm{C}$ to $\mathrm{rt}, 2$ days. (c) aqueous (5\%) $\mathrm{NaOH}, \mathrm{EtOH}, \mathrm{rt}$ to reflux, $24 \mathrm{~h}$.

Conjugate addition reaction was next examined. We had previously shown that conjugate addition reactions of $\alpha$-lithiodithioacetals to the $\alpha, \beta$-unsaturated lactam unit of pyrrolo[2,1$a$ ]isoquinolones does not need the presence of an activating group attached to the unsaturated system to give regio and stereoselectively 1,4 -addition. ${ }^{18}$ Thus, we studied the addition of the $\alpha$ sulfinyl carbanion derived from racemic DITOX to pyrrolo[2,1-a]isoquinolone 1a. The 1,3dithianyllithium could be efficiently prepared by using the mixture of bases NaHMDS $/ n-\mathrm{BuLi}$ at $0^{\circ} \mathrm{C}$. However, although several reaction conditions were tested, the DITOX derived anion was not reactive enough, and no reaction was observed if the lactam 1a was added at this temperature, and the reaction mixture was allowed to warm up to rt. Therefore, we focused our attention on the conjugate addition to $\alpha, \beta$-unsaturated lactam $\mathbf{1 b}$ with an activating benzyloxycarbonyl group at the $\alpha$ position of the lactam carbonyl group. After extensive screening of conditions, it was found that conducting the reaction with $\alpha$-sulfinyl carbanion derived from DITOX (prepared as described above) provided diastereoselectively the trans isomer $\mathbf{2}$ in moderate yield (56\%). However, variable amounts of the product $\mathbf{8}$, formed by addition of lithium trimetylsilylamide were always obtained. The use of the mixture of NaHMDS and $\mathrm{n}-\mathrm{BuLi}$ is crucial for an efficient deprotonation, as no addition product was observed when the bases were used separately. 
<smiles>COc1cc2c(cc1OC)C1(C)C=C(C(=O)Oc3ccccc3)C(=O)N1CC2</smiles>

$(10 \mathrm{bSR})-1 \mathrm{~b}$<smiles>COc1cc2c(cc1OC)[C@]1(C)[C@@H]([C@H]3SCCC[S@]3=O)[C@@H](C(=O)OCc3ccccc3)C(=O)N1CC2</smiles>

(1RS,2RS,10bSR)-2 (56\%)<smiles>COc1cc2c(cc1OC)[C@@]1(C)[C@H](N(C)C)[C@H](C(=O)OCc3ccccc3)C(=O)N1CC2</smiles>

$(1 R S, 2 R S, 10 \mathrm{bSR})-8(12 \%)$

Scheme 5. Reagents and conditions: (a) DITOX, NaHMDS, THF, $-78^{\circ} \mathrm{C}, 10 \mathrm{~min} ; n$-BuLi, $-78^{\circ} \mathrm{C}, 10 \mathrm{~min}$; lactam $\mathbf{1 b}, \mathrm{rt}, 24 \mathrm{~h}$.

NOESY and COSY experiments confirmed the stereochemistry of tetrahydropyrroloisoquinoline 2 . Thus, the $J$ value of the system formed by $\mathrm{H}-1$ and $\mathrm{H}-2$ protons $(J=2.6 \mathrm{~Hz})$ indicates that both protons are in a pseudo-equatorial disposition. Besides, NOE difference spectroscopy showed an enhancement between the methyl group in $\mathrm{C}-10 \mathrm{~b}$ and $\mathrm{H}-1$ and between the methine proton of the 1-oxodithianyl group and $\mathrm{H}-2$. The absence of NOE enhancement between methyl group on $\mathrm{C}-1$ and the 1-oxodithianyl group on $\mathrm{C}-10 \mathrm{~b}$, confirms that they are in a relative trans disposition. The rest of the NOE experiments carried out were fully consistent with the proposed stereochemistry.

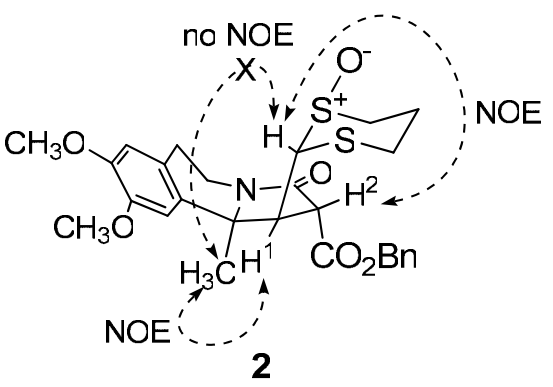

$$
J_{\mathrm{H} 1-\mathrm{H} 2}=2.6 \mathrm{~Hz}
$$

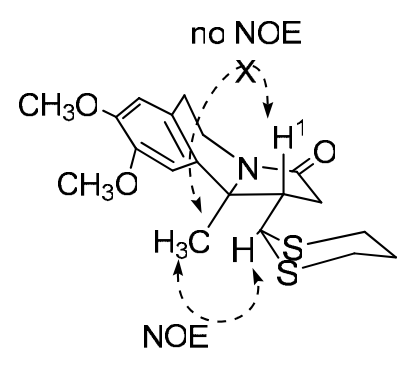

9 (Ref. 18)

Figure 1. Selected NOE enhancements for 2.

It is interesting to note that the 1,10b-trans stereochemistry observed in $\mathbf{2}$ is the opposite of that obtained for the addition of 2-lithio-1,3-dithiane to pyrroloisoquinoline 1a, that afforded the $1,10 \mathrm{~b}$-cis adduct 9 as a single diastereomer. ${ }^{18}$ In this case, the increased bulk of the nucleophile precludes the parallel attack from the exo face, leading to a 1,10b-trans enolate intermediate, which is protonated to give the more stable 1,2-trans adduct (Scheme 6). 


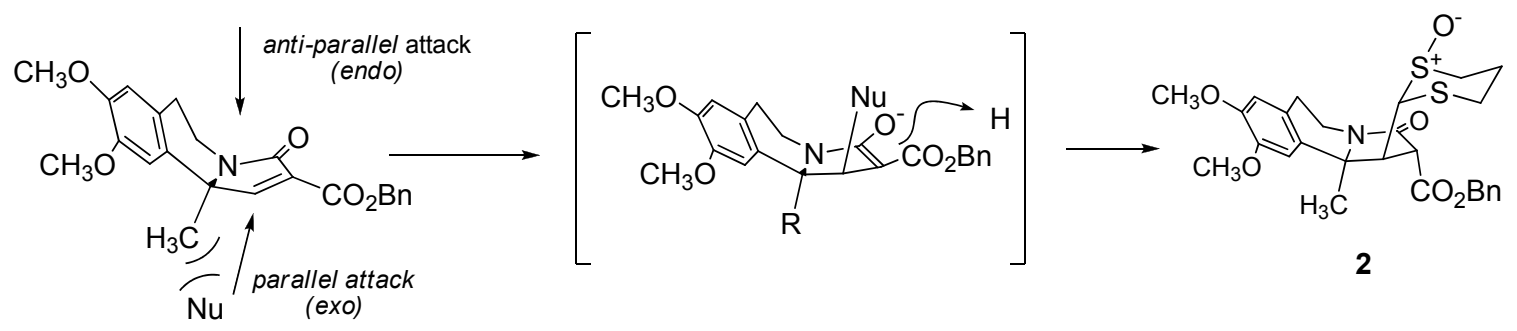

Scheme 6. Stereochemical outcome of the conjugate addition reaction.

In conclusion, in contrast with our previous results with sulfur stabilized anions ${ }^{18}$ the addition of a DITOX derived sulfinyl anion to the $\gamma$-lactam requires the introduction of an electron withdrawing group on C-2, leading to the trans substituted adduct $\mathbf{2}$ in moderate yield and high stereoselectivity.

\section{Experimental Section}

General Procedures. Melting points were determined in unsealed capillary tubes and are uncorrected. IR spectra were obtained on $\mathrm{KBr}$ pellets (solids) or $\mathrm{CHCl}_{3}$ solution (oils). NMR spectra were recorded at $20-25{ }^{\circ} \mathrm{C}$, running at 250 or $300 \mathrm{MHz}$ for ${ }^{1} \mathrm{H}$ and 62.8 or $75.47 \mathrm{MHz}$ for ${ }^{13} \mathrm{C}$ in $\mathrm{CDCl}_{3}$ solutions. Assignment of individual ${ }^{13} \mathrm{C}$ resonances are supported by DEPT experiments. Mass spectra were recorded under electron impact at $70 \mathrm{eV}$. Exact mass was obtained using a TOF detector. GC-MS analyses were performed using a TRB-1 column (methyl polysiloxane, $30 \mathrm{~m} \times 0.25 \mathrm{~mm} \times 0.25 \mu \mathrm{m}$ ). Elemental analyses were performed with a 2400 CHN Perkin-Elmer analyzer at the Servicios Generales de Investigación (SGIker) of the University of the Basque Country. TLC was carried out with $0.2 \mathrm{~mm}$ thick silica gel plates. Visualization was accomplished by UV light. Flash column chromatography ${ }^{19}$ on silica gel was performed with Kiesegel 60 (230-400 mesh). All solvents used in reactions were anhydrous and purified according to standard procedures. ${ }^{20}$ Organolithium reagents were titrated with diphenylacetic acid or $N$-benzyl benzamide periodically prior to use. All air- or moisturesensitive reactions were performed under argon; the glassware was dried $\left(130{ }^{\circ} \mathrm{C}\right)$ and purged with argon.

(1RS)-DITOX (3). A solution of $m$-CPBA $(2.1 \mathrm{~g}, 12.5 \mathrm{mmol})$ in dry $\mathrm{CH}_{2} \mathrm{Cl}_{2}(62 \mathrm{~mL})$ was added over a solution of 1,3-dithiane $(1 \mathrm{~g}, 8.3 \mathrm{mmol})$ in dry $\mathrm{CH}_{2} \mathrm{Cl}_{2}(42 \mathrm{~mL})$ at $0{ }^{\circ} \mathrm{C}$. The reaction mixture was allowed to reach $\mathrm{rt}$ and stirred for $16 \mathrm{~h}$. Then the mixture was washed with (sat.) $\mathrm{Na}_{2} \mathrm{SO}_{3}(3 \times 15 \mathrm{~mL}), \mathrm{H}_{2} \mathrm{O}(1 \times 15 \mathrm{~mL})$ and (sat. $) \mathrm{NaCl}(1 \times 15 \mathrm{~mL})$. The aqueous phase was extracted with $\mathrm{CH}_{2} \mathrm{Cl}_{2}(3 \times 15 \mathrm{~mL})$. The combined organic extracts were dried $\left(\mathrm{Na}_{2} \mathrm{SO}_{4}\right)$ and concentrated in vacuo. Crystallization from $\mathrm{Et}_{2} \mathrm{O}$ afforded (1RS)-DITOX (3) (385 mg, 34\%) as a white solid: $\mathrm{mp}\left(\mathrm{Et}_{2} \mathrm{O}\right): 87-88{ }^{\circ} \mathrm{C}$; IR $(\mathrm{KBr}) 1012 \mathrm{~cm}^{-1} ;{ }^{1} \mathrm{H} \mathrm{NMR}\left(\mathrm{CDCl}_{3}\right)$ 2.16-2.28 (m, $\left.1 \mathrm{H}\right)$, 
2.46-2.71 (m, 4H), 3.28-3.36 (m, 1H), $3.64(\mathrm{~d}, J=12.7 \mathrm{~Hz}, 1 \mathrm{H}), 4.01(\mathrm{~d}, J=12.7 \mathrm{~Hz}, 1 \mathrm{H}) ;{ }^{13} \mathrm{C}$ NMR $\left(\mathrm{CDCl}_{3}\right)$ 27.1, 28.2, 50.3, 52.8; MS (EI) $m / z$ (rel intensity) $136\left(\mathrm{M}^{+}, 77\right), 120$ (6), 119 (37), 106 (41), 91 (13), 90 (73), 87 (90), 85 (26), 83 (18), 78 (17), 74 (40), 73 (100), 72 (22), 71 (14), 69 (19), 64 (17), 63 (25), 61 (87), 60 (67), 59 (30), 57 (27), 55 (41), 54 (14); HRMS calcd for $\mathrm{C}_{4} \mathrm{H}_{8} \mathrm{OS}: 136.0017$. Found: 136.0005 .

(1RS)-2-(2,2-Dimethylpropanoyl)-DITOX (4). A solution of NaHMDS (1.15 mL of a $0.70 \mathrm{M}$ solution in hexanes, $0.81 \mathrm{mmol}$ ) was added over a solution of $(R S)$-DITOX (3) (100 mg, $0.73 \mathrm{mmol})$ in dry THF $(10 \mathrm{~mL})$ at $-78{ }^{\circ} \mathrm{C}$. After $10 \mathrm{~min}, n$-BuLi $(0.6 \mathrm{~mL}$ of a $1.36 \mathrm{M}$ solution in hexanes, $0.81 \mathrm{mmol})$ was added. The resulting solution was stirred at this temperature for $10 \mathrm{~min}$ and $\left(\mathrm{CH}_{3}\right)_{3} \mathrm{CCO}_{2} \mathrm{Et}(0.56 \mathrm{~mL}, 3.68 \mathrm{mmol})$ was added. The reaction mixture was stirred for $2.5 \mathrm{~h}$. The reaction was quenched by the addition of saturated $\mathrm{NH}_{4} \mathrm{Cl}(10 \mathrm{~mL})$. The organic layer was separated and the aqueous phase was extracted with $\mathrm{Et}_{2} \mathrm{O}(1 \times 15 \mathrm{~mL})$ and $\mathrm{CH}_{2} \mathrm{Cl}_{2}(3 \times$ $20 \mathrm{~mL})$. The combined organic extracts were washed with $10 \%$ aq. $\mathrm{NaOH}(2 \times 25 \mathrm{~mL})$, brine $(2 \times 25 \mathrm{~mL})$, and $\mathrm{H}_{2} \mathrm{O}(2 \times 25 \mathrm{~mL})$, then dried $\left(\mathrm{Na}_{2} \mathrm{SO}_{4}\right)$ and concentrated in vacuo. Column chromatography (silicagel, $\mathrm{CH}_{2} \mathrm{Cl}_{2} \quad 100 \% \rightarrow$ AcOEt 100\%) afforded 2-acyl DITOX 4 as mixture of diastereomers in an anti/syn 70:30 diastereomeric ratio (1.37 g, 72\%); IR (KBr) 1701, $1038 \mathrm{~cm}^{-1} ;{ }^{1} \mathrm{H}$ NMR $\left(\mathrm{CDCl}_{3}\right) 1.16$ (s, 9H, syn), 1.18 (s, 9H, anti), 2.03-3.06 (m, 10H, both diastereomers), 3.37-3.46 (m, 1H, anti), 3.81-3.92 (m, 1H, syn), $4.69(\mathrm{~s}, 1 \mathrm{H}$, anti), $4.93(\mathrm{~s}, 1 \mathrm{H}$, syn); ${ }^{13} \mathrm{C} \mathrm{NMR}\left(\mathrm{CDCl}_{3}\right)$ 23.2; 23.6, 25.8; 25.9, 27.7, 28.0, 45.6 (syn), 45.9 (syn), 49.9 (anti), 63.5 (anti), 206.5; 207.4. HRMS calcd for $\mathrm{C}_{9} \mathrm{H}_{16} \mathrm{O}_{2} \mathrm{~S}_{2}: 220.0592$. Found: 204.0598.

(+)-[(8,8-Dimethoxycamphoryl)sulfonyl]imine $\quad(\mathbf{5})^{16}$ A $\quad$ solution of (-)-[(3oxocamphoryl)sulfonyl]imine $(3.0 \mathrm{~g}, 13.2 \mathrm{mmol})$ was added to a solution of $\mathrm{CH}\left(\mathrm{OCH}_{3}\right)_{3}$ (16.5 mL, $150.8 \mathrm{mmol})$ and conc. $\mathrm{H}_{2} \mathrm{SO}_{4}(0.66 \mathrm{~mL})$ in $\mathrm{MeOH}(9 \mathrm{~mL})$. The resulting mixture was heated at $85-90{ }^{\circ} \mathrm{C}$ for $4 \mathrm{~h}$. After allowing the reaction mixture to cooled to $\mathrm{rt}, \mathrm{CH}\left(\mathrm{OCH}_{3}\right)_{3}(4 \mathrm{~mL}$, $36.6 \mathrm{mmol})$ and $\mathrm{MeOH}(1.32 \mathrm{~mL})$ were added and it was heated at $85-90^{\circ} \mathrm{C}$ for $1 \mathrm{~h}$. The organic layer was separated and the aqueous phase was extracted with $\mathrm{CH}_{2} \mathrm{Cl}_{2}(3 \times 25 \mathrm{~mL})$. The combined organic extracts were washed with $\mathrm{H}_{2} \mathrm{O}(2 \times 15 \mathrm{~mL})$ and brine $(2 \times 15 \mathrm{~mL})$, then dried $\left(\mathrm{Na}_{2} \mathrm{SO}_{4}\right)$ and concentrated in vacuo. Crystallization from EtOH afforded imine (+)-5 (3.6 g, 99\%) as a yellow solid: $\mathrm{mp}(\mathrm{EtOH}): 186-188{ }^{\circ} \mathrm{C}$; $[\alpha]^{23}{ }_{\mathrm{D}}+7.6\left(\mathrm{c} 1, \mathrm{CHCl}_{3}\right)$; IR $(\mathrm{KBr}) 1654$, $1331 \mathrm{~cm}^{-1} .{ }^{1} \mathrm{H}$ NMR $\left(\mathrm{CDCl}_{3}\right) 0.95(\mathrm{~s}, 3 \mathrm{H}), 1.05$ (s, 3H), 1.73-2.02 (m, 4H), 2.3 (broad s, 1H), $2.95(\mathrm{~d}, J=13.1 \mathrm{~Hz}, 1 \mathrm{H}), 3.14(\mathrm{~d}, J=13.1 \mathrm{~Hz}, 1 \mathrm{H}), 3.32(\mathrm{~s}, 3 \mathrm{H}), 3.41(\mathrm{~s}, 3 \mathrm{H}) ;{ }^{13} \mathrm{C} \mathrm{NMR}\left(\mathrm{CDCl}_{3}\right)$ 20.4, 20.5, 29.2, 45.9, 48.8, 50.2, 50.5, 51.9, 64.2, 102.9, 188.8; MS (EI) $m / z$ (rel intensity) 273 $\left(\mathrm{M}^{+},<1\right), 209$ (19), 204 (21), 194 (37), 129 (100), 101 (22), 73 (8). HRMS calcd for $\mathrm{C}_{12} \mathrm{H}_{19} \mathrm{NO}_{4} \mathrm{~S}: 273.1035$. Found:273.1042.

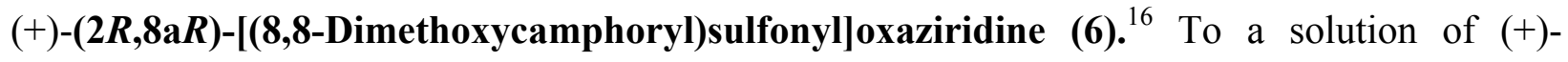
imine 4 (460 mg, $1.68 \mathrm{mmol})$ in dry $\mathrm{CH}_{2} \mathrm{Cl}_{2}(2 \mathrm{~mL})$ at $0{ }^{\circ} \mathrm{C}$, a saturated $\mathrm{K}_{2} \mathrm{CO}_{3}$ solution $(10 \mathrm{~mL})$ was added. After $5 \mathrm{~min}$ under vigorous stirring, a solution of $m$-CPBA (465 $\mathrm{mg}, 2.69 \mathrm{mmol}$ ) in dry $\mathrm{CH}_{2} \mathrm{Cl}_{2}(8 \mathrm{~mL})$ was added. The reaction mixture was stirred at this temperature for $16 \mathrm{~h}$. The organic layer was separated and the aqueous phase was extracted with $\mathrm{CH}_{2} \mathrm{Cl}_{2}(3 \times 20 \mathrm{~mL})$. The combined organic extracts were washed with $\mathrm{H}_{2} \mathrm{O}(1 \times 15 \mathrm{~mL})$, (sat.) $\mathrm{Na}_{2} \mathrm{SO}_{3}(2 \times 15 \mathrm{~mL}), \mathrm{H}_{2} \mathrm{O}$ 
$(1 \times 15 \mathrm{~mL})$, and brine $(2 \times 15 \mathrm{~mL})$, then dried $\left(\mathrm{Na}_{2} \mathrm{SO}_{4}\right)$ and concentrated in vacuo. Crystallization from EtOH afforded oxaziridine (+)-6 (479 mg, 98\%) as a pink solid: $\mathrm{mp}(\mathrm{EtOH})$ 198-200 ${ }^{\circ} \mathrm{C} ;[\alpha]^{23}$ : +89.0 (c 2.7, $\mathrm{CHCl}_{3}$ ); IR (KBr) $1353 \mathrm{~cm}^{-1} ;{ }^{1} \mathrm{H} \mathrm{NMR}\left(\mathrm{CDCl}_{3}\right) 1.04$ (s, 3H), $1.30(\mathrm{~s}, 3 \mathrm{H}), 1.75-1.95(\mathrm{~m}, 4 \mathrm{H}), 2.26(\mathrm{~d}, J=4.0 \mathrm{~Hz}, 1 \mathrm{H}), 3.05(\mathrm{~d}, J=13.9 \mathrm{~Hz}, 1 \mathrm{H}), 3.24(\mathrm{~d}, J=$ $13.9 \mathrm{~Hz}, 1 \mathrm{H}), 3.25(\mathrm{~s}, 3 \mathrm{H}), 3.32(\mathrm{~s}, 3 \mathrm{H}) ;{ }^{13} \mathrm{C} \mathrm{NMR}\left(\mathrm{CDCl}_{3}\right)$ 20.4, 21.6, 28.0, 45.1, 47.4, 50.5, 50.8, 52.8, 54.5, 97.6, 102.7; MS (EI) $m / z$ (rel intensity) $289\left(\mathrm{M}^{+},<1\right), 129$ (14), 109 (100), 108 (19), 93 (54), 91 (11), 67 (16). HRMS calcd for $\mathrm{C}_{12} \mathrm{H}_{19} \mathrm{NO}_{5} \mathrm{~S}: 289.0984$. Found:289.0992.

2-(2,2-Dimethylpropanoyl)-1,3-dithiane (7). ${ }^{17}$ A solution of NaHMDS (18.3 mL of a $0.70 \mathrm{M}$ solution in hexanes, $12.8 \mathrm{mmol}$ ) was added over a solution of 1,3-dithiane (1.32 $\mathrm{g}, 10.7 \mathrm{mmol})$ in dry THF $(20 \mathrm{~mL})$ at $0{ }^{\circ} \mathrm{C}$. The resulting solution was stirred at $\mathrm{rt}$ for $1 \mathrm{~h}$ and $n$-BuLi $(9.15 \mathrm{~mL}$ of a1.4 $\mathrm{M}$ solution in hexanes, $12.8 \mathrm{mmol})$ was added. After $30 \mathrm{~min}$ at $\mathrm{rt},\left(\mathrm{CH}_{3}\right)_{3} \mathrm{CCO}_{2} \mathrm{Et}(1.96 \mathrm{~mL}$, $12.8 \mathrm{mmol}$ ) was added and the reaction mixture was stirred for $2.5 \mathrm{~h}$. The reaction was quenched by the addition of saturated $\mathrm{NH}_{4} \mathrm{Cl}(10 \mathrm{~mL})$. The organic layer was separated and the aqueous phase was extracted with $\mathrm{Et}_{2} \mathrm{O}(1 \times 15 \mathrm{~mL})$ and $\mathrm{CH}_{2} \mathrm{Cl}_{2}(3 \times 20 \mathrm{~mL})$. The combined organic extracts were dried $\left(\mathrm{Na}_{2} \mathrm{SO}_{4}\right)$ and concentrated in vacuo to afford 2-acyl-1,3-dithiane 7 (1.37 g, 63\%) as a white solid: $\mathrm{mp}\left(\mathrm{Et}_{2} \mathrm{O}\right): 109-11{ }^{\circ} \mathrm{C}$; IR $(\mathrm{KBr}) 1688 \mathrm{~cm}^{-1} ;{ }^{1} \mathrm{H} \mathrm{NMR}\left(\mathrm{CDCl}_{3}\right) 1.17$ (s, $9 \mathrm{H}), 1.85-2.15(\mathrm{~m}, 2 \mathrm{H}), 2.45-2.53(\mathrm{~m}, 2 \mathrm{H}), 3.31-3.42(\mathrm{~m}, 2 \mathrm{H}), 4.45(\mathrm{~s}, 1 \mathrm{H}) ;{ }^{13} \mathrm{C} \mathrm{NMR}\left(\mathrm{CDCl}_{3}\right)$ 24.9, 25.3, 26.8, 38.0, 44.2, 208.6; MS (EI) $m / z$ (rel intensity) $204\left(\mathrm{M}^{+},<1\right), 119$ (3), 87 (5), 85 (51), 83 (100), 71 (5), 57 (9), 55 (3). HRMS calcd for $\mathrm{C}_{9} \mathrm{H}_{16} \mathrm{OS}_{2}: 204.0643$. Found: 204.0650.

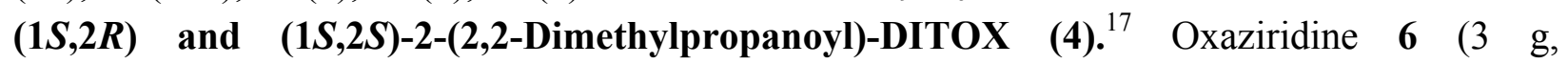
$10.35 \mathrm{mmol})$ was added to a solution of 2-acyl-1,3-dithiane $7(1.37 \mathrm{~g}, 6.73 \mathrm{mmol})$ in $\mathrm{CCl}_{4}$ $(80 \mathrm{~mL})$ at $0{ }^{\circ} \mathrm{C}$. The reaction mixture was allowed to reach $\mathrm{rt}$, stirred at this temperature for 2 days, and then filtered off. Column chromatography (silicagel, $\mathrm{CH}_{2} \mathrm{Cl}_{2} \quad 100 \% \rightarrow \mathrm{AcOEt} 100 \%$ ) afforded 2-acyl-DITOX 4 as mixture of diastereomers in an anti/syn 70:30 diastereomeric ratio $(1.47 \mathrm{~g}, 99 \%)$. The spectroscopic data were identical to those of the corresponding racemate. To the diastereomeric mixture of $(1 S, 2 R)$ and $(1 S, 2 S)$-2-(2,2-dimethylpropanoyl)-DITOX (4) $(237 \mathrm{mg}, 1.08 \mathrm{mmol})$ aqueous $(15 \%) \mathrm{NaOH}(1.44 \mathrm{~mL})$ and $\mathrm{EtOH}(3.6 \mathrm{~mL})$ were added. The reaction mixture was heated under reflux for $24 \mathrm{~h}$. Crystallization from $\mathrm{Et}_{2} \mathrm{O}$ afforded (1S)-(-)DITOX (3) (98 mg, 67\%) as a white solid: $\mathrm{mp}\left(\mathrm{Et}_{2} \mathrm{O}\right)$ : $91-93{ }^{\circ} \mathrm{C}$; $[\alpha]^{23}{ }_{\mathrm{D}}-119.9\left(\mathrm{c} 1, \mathrm{CHCl}_{3}\right)$. The enantiomeric excess determined] by CSP HPLC was $>99 \%$ by comparison with the racemic mixture. Chiralcel OC, 9\% hexane/2-propanol, $1 \mathrm{~mL} / \mathrm{min} ; \mathrm{t}_{\mathrm{r}}=39.3 \mathrm{~min}(83 \%) ; \mathrm{t}_{\mathrm{r}}[(1 R)-1 \mathrm{a}]=$ $48.9 \mathrm{~min}(17 \%)$. The spectroscopic data were identical to those of the corresponding racemate.

Conjugate addition of DITOX to pyrrolo[2,1-a]isoquinolones. Synthesis of (1RS,2SR,10bSR)-2-benzyloxycarbonyl-8,9-dimethoxy-10b-methyl-1-(1-oxo-1,3-dithian-2yl)-1,5,6,10b-tetrahydropyrrolo[2,1-a]isoquinolin-3-one (2) and (1RS,2SR,10bSR)-2benzyloxycarbonyl-1-(1,1,1,3,3,3-hexamethyldisilazan-2-yl)-10b-methyl-8,9-dimethoxy1,5,6,10b-tetrahydropyrrolo[2,1-a]isoquinolin-3-one (8). A solution of NaHMDS $(0.36 \mathrm{~mL}$ of a $0.70 \mathrm{M}$ solution in hexanes, $0.25 \mathrm{mmol}$ ) was added over a solution of DITOX (3) (32 $\mathrm{mg}, 0.23$ $\mathrm{mmol})$ in dry THF $(10 \mathrm{~mL})$ at $-78^{\circ} \mathrm{C}$. After $10 \mathrm{~min}, n$-BuLi $(0.19 \mathrm{~mL}$, of a $1.36 \mathrm{M}$ solution in hexanes, $0.25 \mathrm{mmol}$ ) was added. After $10 \mathrm{~min}$, a solution of pyrroloisoquinolone $\mathbf{1 b}$ (109.3 $\mathrm{mg}$, 
$0.28 \mathrm{mmol})$ in dry THF $(5 \mathrm{~mL})$ was added. The resulting solution was stirred at $\mathrm{rt}$ for $24 \mathrm{~h}$. The reaction was quenched by addition of $\mathrm{NH}_{4} \mathrm{OH}(12 \%$ aq.) $(10 \mathrm{~mL})$. The organic layer was separated and the aqueous phase was extracted with $\mathrm{Et}_{2} \mathrm{O}(10 \mathrm{~mL})$ and $\mathrm{CH}_{2} \mathrm{Cl}_{2}(3 \times 15 \mathrm{~mL})$. The combined organic extracts were dried $\left(\mathrm{Na}_{2} \mathrm{SO}_{4}\right)$ and concentrated in vacuo. Column chromatography (silicagel, 96\% hexane/AcOEt) afforded adducts $\mathbf{2}$ and $\mathbf{8}$. Both compounds were separated by chromatography and characterized separately. (1RS,2SR,10bSR)-2-benzylcarbonyl8,9-dimethoxy-10b-methyl-1-(1-oxo-1,3-dithian-2-yl)-1,5,6,10b-tetrahydropyrrolo[2,1a] isoquinolin-3-one (2), oil (83 mg, 56\%): IR (KBr) 1736, 1698, $1032 \mathrm{~cm}^{-1} ;{ }^{1} \mathrm{H} \mathrm{NMR}\left(\mathrm{CDCl}_{3}\right)$ $1.55(\mathrm{~s}, 3 \mathrm{H}), 1.72-2.01(\mathrm{~m}, 1 \mathrm{H}), 2.24-2.28(\mathrm{~m}, 1 \mathrm{H}), 2-33-2.44(\mathrm{~m}, 3 \mathrm{H}), 2.57-2.62(\mathrm{~m}, 1 \mathrm{H}), 2.89-$ $2.97(\mathrm{~m}, 1 \mathrm{H}), 3.02-3,08(\mathrm{~m}, 1 \mathrm{H}), 3.20-3.23(\mathrm{~m}, 1 \mathrm{H}), 3.55(\mathrm{~d}, J=2.6 \mathrm{~Hz}, 1 \mathrm{H}), 3.60\left(\mathrm{~s}, 1 \mathrm{H}^{\prime}\right), 3.88$ $(\mathrm{s}, 3 \mathrm{H}), 3.99(\mathrm{~s}, 3 \mathrm{H}), 3.95-4.02(\mathrm{~m}, 1 \mathrm{H}), 4.36-4.39(\mathrm{~m}, 1 \mathrm{H}), 5.24(\mathrm{~d}, J=12.2 \mathrm{~Hz}, 1 \mathrm{H}), 5.31(\mathrm{~d}, J$ $=12.2 \mathrm{~Hz}, 1 \mathrm{H}), 6.55(\mathrm{~s}, 1 \mathrm{H}), 6.99(\mathrm{~s}, 1 \mathrm{H}), 7.30-7.47(\mathrm{~m}, 5 \mathrm{H}) ;{ }^{13} \mathrm{C} \mathrm{NMR}\left(\mathrm{CDCl}_{3}\right) 28.7,29.3,30.5$, 31.6, 35.6, 45.4, 55.7, 55.8, 56.0, 63.1, 67.8, 72.4, 110.5, 111.3, 126.6, 128.0, 135.1, 128.5, 128.6, 128.7, 147.1, 148.2, 165.8, 168.7; MS (EI) $\mathrm{m} / z$ (rel intensity) $530\left(\mathrm{M}^{+}+1,3\right), 529\left(\mathrm{M}^{+}, 9\right)$, $514\left(\mathrm{M}^{+}-15,2\right), 395$ (11), 378 (2), 316 (23), 273 (5), 272 (8), 244 (6), 207 (14), 206 (100), 205 (9), 204 (9), 197 (5), 190 (9), 119 (9), 108 (12), 107 (9), 106 (6), 91 (58), 90 (18), 85 (6), 79 (15), 77 (9), 71 (7), 57 (9), 55 (6). Anal. Calcd for $\mathrm{C}_{27} \mathrm{H}_{31} \mathrm{NO}_{6} \mathrm{~S}_{2}$ : C, 61.22; H, 5.90; N, 2.64. Found: C, 60.97; H, 5.84; N, 2.72. Minor compound 8, oil (19 mg, 12\%); IR (KBr) 1740, $1694 \mathrm{~cm}^{-1} ;{ }^{1} \mathrm{H}$ NMR $\left(\mathrm{CDCl}_{3}\right)-0.12(\mathrm{~s}, 6 \mathrm{H}),,-0.08(\mathrm{~s}, 3 \mathrm{H}), 0.35(\mathrm{~s}, 6 \mathrm{H}), 0.40(\mathrm{~s}, 3 \mathrm{H}), 1.61(\mathrm{~s}, 3 \mathrm{H}), 2.56-2.62(\mathrm{~m}$, $1 \mathrm{H}), 2.84-2,91(\mathrm{~m}, 2 \mathrm{H}), 3.86-3.93(\mathrm{~m}, 1 \mathrm{H}), 3.86(\mathrm{~s}, 3 \mathrm{H}), 3.87(\mathrm{~s}, 3 \mathrm{H}), 4.10(\mathrm{~d}, J=11.1 \mathrm{~Hz}, 1 \mathrm{H}$, 4.35-4.41 (m, 1H), $5.19(\mathrm{~d}, J=4.8 \mathrm{~Hz}, 2 \mathrm{H}), 6.58(\mathrm{~s}, 1 \mathrm{H}), 6.78(\mathrm{~s}, 1 \mathrm{H}), 7.33-7.34(\mathrm{~m}, 5 \mathrm{H}) ;{ }^{13} \mathrm{C}$ NMR $\left(\mathrm{CDCl}_{3}\right)$ 3.1, 5.6, 24.0, 29.3, 35.0, 55.2, 55.7, 56.3, 63.8, 67.0, 67.4, 110.2, 111.8 , 125.6, $128.1,128.2,128.4,131.5,135.3,147.3,147.9,166.8,169.6$; MS (EI) $m / z$ (rel intensity) 555 (M ${ }^{+}$ +1, 5), $554\left(\mathrm{M}^{+}, 12\right), 539$ (6), 455 (8), 378 (22), 364 (19), 306 (15), 262 (8), 258 (11), 244 (11), 214 (13), 206 (47), 205 (100), 204 (9), 190 (12), 146 (14), 130 (8), 100 (7), 99 (6), 91 (63), 79 (5), 77 (5), 73 (39), 65 (5). Anal. Calcd for $\mathrm{C}_{29} \mathrm{H}_{42} \mathrm{~N}_{2} \mathrm{O}_{5} \mathrm{Si}_{2}: \mathrm{C}, 62.78 ; \mathrm{H}, 7.63$; N, 5.05. Found: C, $62.49 ; \mathrm{H}, 7.46 ; \mathrm{N}, 5.12$.

\section{Acknowledgements}

Financial support from MICINN (CTQ2006-01903), Gobierno Vasco (GIC07/92-IT-227-07), and Universidad del País Vasco is gratefully acknowledged.

\section{References}

1. (a) Perlmutter, P. Conjugate Addition Reactions in Organic Synthesis, Baldwin, J. E.; Magnus, P. D., Eds; Tetrahedron Organic Chemistry Series, Pergamon Press: Oxford, 1992, 
Vol. 9. (b) Rossiter, B. E.; Swingle, N. M. Chem. Rev. 1992, 92, 771. (c) Leonard, J.; DíezBarra, E.; Merino, S. E. J. Org. Chem. 1998, 2051. (d) Yamamguchi, M. In Comprehensive Asymmetric Catalysis I-III, Jacobsen, E. N.; Pfaltz, A.; Yamamoto, H. Eds.; Springer: Berlin, 1999, Vol. 3, pp 1121. (e) Jha, S. C.; Joshi, N. N. Arkivoc 2002, 167. (f) Iguchi, M.; Yamada, K.; Tomioka, K. In Organolithiums in Enantioselective Synthesis, Hodgson, D. M., Ed.; Topics in Organometallic Chemistry, Springer: Berlin, 2003, Vol. 5, pp 21-36. (g) Davies, S. G.; Smith, A. D.; Price, P. D. Tetrahedron: Asymmetry 2005, 16, 2833. (h) Wu, G.; Huang, M. Chem. Rev. 2006, 106, 2596. (i) López, F.; Minnaard, A. J.; Feringa, B. L. Acc. Chem. Res. 2007, 40, 179. (j) Alexakis, A.; Backvall, J. E.; Krause, N.; Pamies, O.; Dieguez, M. Chem. Rev. 2008, 108, 2796. (k) Harutyunyan, S. R.; den Hartog, T.; Geurts, K.; Minnaard, A. J.; Feringa, B. L. Chem. Rev. 2008, 108, 2824.

2. For reviews on asymmetric conjugate additions with sulfoxide stabilized carbanions, see: (a) Solladié, G. In Asymmetric Synthesis; Morrison, J. D., Ed.; Academic Press: New York, 1983; Vol. 2, pp 157. (b) Posner, G. H. In The Chemistry of Sulfones and Sulfoxides; Patai, S., Rappoport, Z., Striling, C. J. M., Eds.; Wiley-Interscience: New York, 1988; pp 823-849. (c) Walker, A.-J. Tetrahedron: Asymmetry 1992, 3, 961. (d) Carreño, M. C. Chem. Rev. 1995, 95, 1717. (e) Allin, S. M.; Shuttleworth, S. J.; Page, P. C. B. Organosulfur Chem. 1998, 2, 97. (f) Fernández, I.; Khiar, N. Chem. Rev. 2003, 103, 3651. (g) Pellissier, H. Tetrahedron 2006, 62, 5559.

3. (a) Nakamura, S.; Takemoto, H.; Ueno, Y.; Toru, T.; Kakumoto, T.; Hagiwara, T. J. Org. Chem. 2000, 65, 469. (b) Nakamura, S.; Watanabe, Y.; Toru, T. J. Org. Chem. 2000, 65, 17586. (c) Nakamura, S.; Uchiyama, Y.; Ishikawa, S.; Fukinbara, R.; Watanabe, Y.; Toru, T. Tetrahedron Lett. 2002, 43, 2381.

4. Acherki, H.; Alvarez-Ibarra, C.; de Dios, A.; Gutiérrez, M.; Quiroga, M. L. Tetrahedron: Asymmetry 2001, 12, 3173.

5. Nowaczyk, S.; Alayrac, C.; Metzner, P.; Averbuch-Pouchot, M-T. J. Org. Chem. 2002, 67, 6852.

6. (a) Page, P. C. B.; Heer, J. P.; Bethell, D.; Collington, E. W.;Andrews, D. M. Synlett 1995, 773. (b) Page, P. C. B.; Heer, J. P.; Bethell, D.; Collington, E. W.; Andrews, D. M. Tetrahedron: Asymmetry 1995, 6, 2911. (c) Allin, S. M.; Page, P. C. B. Org. Prep. Proc. Int. 1998, 30, 145.

7. (a) Carey, F. A.; Dailey, O. D.; Hernandez, O. J. Org. Chem. 1976, 41, 3979. (b) Auret, B. J.; Boyd, D. R.; Cassidy, E. S.; Hamilton, R.; Turley, F.; Drake, A. F. J. Chem. Soc., Perkin Trans. I 1985, 1547. (c) Page, P. C. B.; Shuttleworth, S. J.; Schilling, M. B.; Tapolczay, D. J. Tetrahedron Lett. 1993, 34, 6947.

8. (a) Carlson, R. M.; Helquist, P. M. J. Org. Chem. 1968, 33, 2596. (b) Page, P. C. B.; Gareh, M. T.; Porter, R. A. Tetrahedron Lett. 1993, 34, 5159. (c) Page, P. C. B.; Purdie, M.; 
Lathbury, D. Tetrahedron Lett. 1996, 37, 8929. (d) Fang, J-M.; Chou, W-C.; Lee, G-H.; Peng, S-M. J. Org. Chem. 1990, 55, 5515.

9. Page, P. C. B.; McKenzie, M. J.; Allin, S. M.; Buck, D. R. Tetrahedron 2000, 56, 9683.

10. For some representative examples, see: reductions (a) Barros, M. T.; Leitão, A. J.; Maycock, C. D. Tetrahedron Lett. 1995, 36, 6537. Nucleophilic additions (b) Page, P. C. B.; Prodger, J. C.; Westwood, D. Tetrahedron 1993, 49, 10355. (c) García Ruano, J. L.; Barros, D.; Maestro, M. C.; Slawin, A. M. Z.; Page, P. C. B. J. Org. Chem. 2000, 65, 6027. Ketones $\alpha-$ Alkylation (d) Page, P. C. B.; Allin, S. M.; Collington, E. W.; Carr, R. A. E. Tetrahedron Lett. 1994, 35, 2607. (e) Page, P. C. B.; McKenzie, M. J.; Allin, S. M.; Klair, S. S. Tetrahedron 1997, 53, 13149. Dihydroxylation (f) Page, P. C. B.; McKenzie, M. J.; Buckle, D. R. Tetrahedron 1998, 54, 14581. Conjugate addition (g) Page, P. C. B.; Prodger, J. C.; Hursthouse, M. B.; Mazid, M. J. Chem. Soc., Perkin Trans. I 1990, 167. Cicloaddition (h) Page, P. C. B.; McKenzie, M. J.; Buckle, D. R. Tetrahedron 1998, 54, 14573.

11. García, E.; Lete, E.; Sotomayor, N. J. Org. Chem. 2006, 71, 6776.

12. For examples of low reactivity of $\alpha, \beta$-unsaturated amides and lactams in 1,4-addition reactions, see: (a) Brewster, A. G.; Broady, S.; Hughes, M.; Moloney, M. G.; Woods, G. Org. Biomol. Chem. 2004, 2, 1800, and references therein. For examples for 1,4-addition reactions of sulfur-stabilized anions to lactams, see: (b) Mpango, G. B.; Mahalanabis, K. K.; Damghani, Z. M.; Snieckus, V. Tetrahedron Lett. 1980, 21, 4823. (c) Mpango, G. B.; Snieckus, V. Tetrahedron Lett. 1980, 21, 4827. (d) Hashimoto, M.; Hashimoto, K.; Shirahama, H. Tetrahedron 1996, 52, 1931. (e) Forns, P.; Díez, A.; Rubiralta, M. Tetrahedron 1996, 52, 3563. (f) Forns, P.; Díez, A.; Rubiralta, M. J. Org. Chem. 1996, 61, 7882. (g) Amat, M.; Pérez, P., Llor, N.; Bosch, J. Org. Lett. 2002, 4, 2787.

13. Camarero, C.; González-Temprano, I.; Lete, E.; Sotomayor, N. Synlett 2007, 1101.

14. Osante, I. Abdullah, M. N.; Arrasate, S.; Sotomayor, N.; Lete, E. Arkivoc 2007; 206.

15. (a) Nickon, A.; Rodríguez, A. D.; Shirhatti, V.; Ganguly, R. J. Org. Chem. 1985, 50, 4218. (b) Aggarwal, V. K.; Davies, I. W.; Franklin, R. J.; Maddock, J.; Mahon, M. F.; Molloy, K. C. J. Chem. Soc., Perkin Trans. I 1994, 2363.

16. Chen, B. C.; Murphy, C. K.; Kumar, A.; Reddy, R. T.; Clark, C.; Zhou, P.; Lewis, B. M.; Gala, D.; Mergelsberg, I.; Scherer, D.; Buckley, J.; Di Benedetto, D.; Davis, F. A. Org. Synth.; 1996, 73, 159.

17. Page, P. C. B.; Heer, J. P.; Bethell, D.; Collington, E. W.; Andrews, D. M. Org. Synth.; 1999, 76, 37.

18. Etxarri, B.; González-Temprano, I.; Manteca, I.; Sotomayor, N.; Lete, E. Synlett 1999, 1486.

19. Still, W. C.; Kann, H.; Mitra, A. J. J. Org. Chem. 1978, 43, 2923.

20. Perrin, D. D.; Armarego, W. L. F. Purification of Laboratory Chemicals; Pergamon Press: Oxford, 1997. 